\title{
Apakah insentif keuangan dan persepsi keseriusan berpengaruh terhadap keputusan aparatur sipil negara melakukan whistleblowing?
}

\author{
Andrey Hasiholan Pulungan*1, Indri Afriani ${ }^{1}$, Albert Hasudungan ${ }^{2}$ \\ ${ }^{1}$ Universitas Sampoerna, Indonesia \\ ${ }^{2}$ STIE Prasetiya Mulya, Indonesia
}

Diterima: Juli 2019

Direvisi: Desember 2019

Disetujui: Desember 2019

Koresponding:

Andrey Hasiholan

Pulungan

afrianiindri@gmail.com

DOI:

http://dx.doi.org/10.17977/

um004v7i12020p1

\begin{abstract}
This study aims to examine the influence of perception of seriousness and financial incentives on public officers' decisions to conduct whistleblowing to external parties. Two independent variables in this study, perception of seriousness and financial incentives, are based on extrinsic-intrinsic motivation theory. This research used the experimental between-subject method so there were two types of questionnaire distributed to public officers in three different public institutions, selected by using the convenience sampling method. The ancova test results show that public officers' decisions to report violations is influenced by the seriousness of the violation. Meanwhile, the impact of financial incentives on whistleblowing intentions is insignificant. The interaction between perceptions of seriousness and financial incentives also indicates that regardless of the existence of monetary rewards, the more serious a violation is, the greater the intention of public officers to report violations. This study contributes to academic literature and policymakers. It extends fraud detection literature and provides evidence to policy makers about the impact of perception of seriousness and financial incentives on public officers' intention to report fraud.
\end{abstract}

Keywords: whistleblowing; public officer; financial incentive; perceived seriousness

\begin{abstract}
Abstrak
Penelitian ini bertujuan untuk menguji pengaruh persepsi keseriusan dan insentif keuangan terhadap keputusan aparatur sipil negara (ASN) melakukan whistleblowing kepada pihak eksternal. Kedua variabel independent yang diuji di dalam penelitian ini, yaitu persepsi keseriusan dan insentif keuangan, didasarkan pada teori motivasi ekstrinsik-intrinsik. Penelitian ini menggunakan metode experimental between-subject sehingga ada dua jenis kuesioner disebarkan ke ASN di tiga institusi yang berbeda. Responden hanya diperbolehkan mengisi salah satu kuesioner. Pemilihan responden dilakukan dengan menggunakan metode convenience sampling. Hasil uji ancova memperlihatkan bahwa keputusan aparatur sipil negara dalam melaporkan pelanggaran dipengaruhi oleh seberapa serius pelanggaran tersebut (persepsi keseriusan). Dampak insentif keuangan terhadap intensi whistleblowing tidak signifikan. Interaksi antara persepsi keseriuan dan insentif keuangan mengindikasikan bahwa terlepas dari keberadaan imbalan moneter, semakin serius suatu pelanggaran, semakin besar pula intensi ASN melaporkan pelanggaran. Studi ini berkontribusi pada literatur akademis dan pembuat kebijakan. Penelitian ini memperdalam literatur mengenai pendeteksian kecurangan dan memberikan bukti kepada pembuat kebijakan mengenai dampak persepsi keseriusan dan insentif keuangan terhadap intensi aparatur sipil negara untuk melaporkan kecurangan.
\end{abstract}

Kata Kunci: whistleblowing; aparatur sipil negara; insentif keuangan; persepsi keseriusan

\section{PENDAHULUAN}

Studi ini bertujuan untuk menguji hubungan antara persepsi keseriusan dan insentif keuangan terhadap intensi whistleblowing aparatur sipil negara. Whistleblowing adalah pengungkapan secara sukarela oleh anggota organisasi atau mantan anggota organisasi mengenai praktik ilegal, tidak bermoral, atau tidak sah, kepada pihak yang mungkin dapat melakukan penindakan (Near \& Miceli, 1985). Pemerintah Indonesia mendorong praktik whistleblowing untuk memberantas berbagai kecurangan yang terjadi di lingkungan pemerintahan. Komisi Pemberantasan Korupsi (KPK 2017, 2018) menyatakan tiga modus tindak pidana korupsi yaitu penyuapan, pengadaan barang dan/atau jasa, dan pencucian uang. Kasus yang ditangani KPK dari tahun 2014 hingga 2018 mencapai 489 kasus (Tabel 1). Pelaku kejahatan keuangan melibatkan pihak swasta, anggota DPR/DPRD, Eselon 
Tabel 1. Modus Tindak Pidana Korupsi Terbanyak yang Ditangani KPK Periode 2014-2018

\begin{tabular}{lcccccc}
\hline \multicolumn{1}{c}{ Jabatan } & 2014 & 2015 & 2016 & 2017 & 2018 & Jumlah \\
\hline Swasta & 16 & 18 & 28 & 28 & 50 & 140 \\
Anggota DPR dan DPRD & 9 & 19 & 23 & 20 & 91 & 162 \\
Eselon I, II, III dan IV & 2 & 7 & 10 & 43 & 20 & 82 \\
Walikota/Bupati dan Wakil & 12 & 4 & 9 & 13 & 28 & 66 \\
\hline
\end{tabular}

Sumber: Komisi Pemberantasan Korupsi (2017 dan 2018)

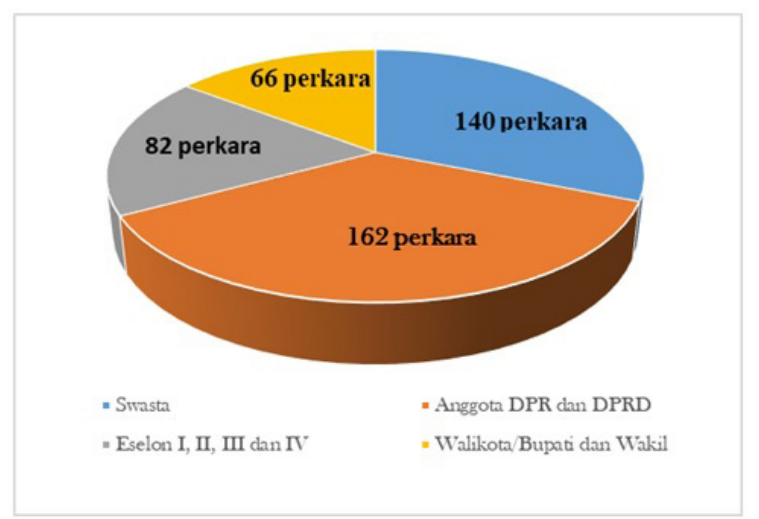

Gambar 1. Pelaku Kejahatan Keuangan (Sumber: Komisi Pemberantasan Korupsi, 2017, 2018)

Tabel 2. Insentif Keuangan Kepada Pelapor

\begin{tabular}{lll}
\hline \multicolumn{1}{c}{ Jenis Pidana } & \multicolumn{1}{c}{ Insentif Keuangan } & \multicolumn{1}{c}{$\begin{array}{c}\text { Jumlah Maksimal Insentif } \\
\text { Keuangan }\end{array}$} \\
\hline Korupsi & $2 / 1000 \times$ Kerugian negara yang dapat dikembalikan ke negara & Rp200.000.000,- \\
Suap & $2 / 100 \times$ Nilai suap dan/atau barang rampasan & Rp10.000.000,- \\
\hline
\end{tabular}

Sumber: Republik Indonesia (2018)

I-IV, dan Walikota/Bupati dan Wakil (Gambar 1). Dalam rangka mendeteksi kecurangan yang merugikan negara sedini mungkin, Pemerintah menerbitkan Peraturan Pemerintah No 43 Tahun 2018 yang mengatur pemberian penghargaan dalam bentuk uang kepada whistleblower. Tujuannya adalah untuk meningkatkan peran aktif masyarakat secara luas untuk melakukan whistleblowing terhadap kasus-kasus korupsi di sektor publik. Besarnya premi atau insentif keuangan diatur di dalam pasal 17 (Tabel 2).

Teori motivasi intrinsik dan ekstrinsik (Ryan \& Deci, 2000) mengemukakan bahwa motivasi seseorang melakukan tindakan atau keputusan dapat berasal dari dalam atau luar diri seseorang. Motivasi ekstrinsik membuat seseorang melakukan suatu kegiatan bukan untuk kepuasan dirinya, tetapi untuk mencapai suatu hasil dari sekitarnya seperti menerima penghargaan atau menghindari hukuman (Deci \& Ryan, 1985; Kruglanski, 1978). Salah satu bentuk penghargaan yang dapat memotivasi seseorang adalah insentif keuangan. Sebagai contoh, insentif keuangan dapat lebih memotivasi seorang aparatur sipil negara (ASN) untuk pekerjaan-pekerjaan yang dianggap kurang menarik, misalnya pekerjaan yang tidak memerlukan pengalaman dalam membuat kebijakan (Weibel, Rost, \& Osterloh, 2010). ASN pada tingkatan yang rendah cenderung menilai pekerjaan kurang menarik dibandingkan pekerjaan para ASN setingkat manajer. Oleh sebab itu, pemberian insentif keuangan sebagai cara untuk meningkatkan kinerja sangat direkomendasikan bagi ASN dengan tingkatan yang rendah (Buelens \& Van Den Broeck, 2007).

Secara umum, insentif keuangan berdampak positif terhadap intensi individu melaporkan adanya pelanggaran. Xu dan Ziegenfuss (2008) menemukan bahwa kecenderungan auditor internal melaporkan pelanggaran akan meningkat apabila mereka menerima insentif keuangan untuk melakukan pelaporan. Intensi pegawai perusahaan untuk melaporkan kecurangan juga akan meningkat saat mereka ditawarkan imbalan moneter (Stikeleather, 2016; Andon, Free, Jidin, Monroe, \& Turner, 2018). Akan tetapi, hasil penelitian Pope dan Lee (2012) serta Brink et al (2013) menunjukkan bahwa pengaruh insentif yang diberikan dari internal perusahaan terhadap intensi whistleblowing tidak begitu jelas. Pope dan Lee (2012) menemukan adanya social desirability bias dalam penelitian mereka. Partisipan memprediksi bahwa insentif keuangan hanya memengaruhi secara signifkan keputusan melakukan whistleblowing yang dilakukan orang lain. Di sisi lain, pengaruh insentif 
keuangan tidak signifikan apabila whistleblowing dilakukan oleh partisipan sendiri. Brink et al (2013) melaporkan bahwa insentif keuangan internal organisasi tidak meningkatkan intensi individu untuk melaporkan pelanggaran kepada pihak-pihak di dalam internal perusahaan. Hal tersebut berbeda dengan dampak insentif keuangan yang ditawarkan oleh Stock Exchange Commission (SEC) dimana insentif keuangan menyebabkan kecenderungan individu melaporkan pelanggaran kepada SEC (pihak eksternal) meningkat signifikan.

Berbeda dengan motivasi ekstrinsik, motivasi intrinsik menekankan individu melakukan sesuatu karena dianggap menarik atau menyenangkan untuk melakukan sesuatu hal tersebut (Ryan \& Deci, 2000). Salah satu faktor intrinsik yang dapat memengaruhi keputusan seseorang melakukan whistleblowing adalah persepsi atas keseriusan suatu pelanggaran. Persepsi keseriusan terkait dengan bagaimana individu mengevaluasi suatu isu atau kejadian yang dipengaruhi oleh karakteristik situasi dan siapa yang terlibat, termasuk seberapa besar kemungkinan dan seberapa signifikan kejadian tersebut berdampak negatif ke orang lain (Curtis, 2006). Ketika seseorang menganggap semakin serius sebuah pelanggaran, maka kecederungan orang tersebut untuk melaporkan pelanggaran yang terjadi akan semakin tinggi (Taylor \& Curtis, 2013). Andon et al (2018) yang melakukan penelitian eksperimental dengan menggunakan akuntan di perusahaan swasta sebagai partisipan, juga menemukan bahwa ketika individu menganggap suatu pelanggaran semakin serius, semakin besar intensi individu untuk melaporkan pelanggaran tersebut.

Penelitian ini dimotivasi oleh dua alasan. Alasan pertama adalah dampak insentif keuangan yang ditawarkan melalui Peraturan Pemerintah No 43 Tahun 2018 masih perlu diteliti lebih lanjut. Winardi (2013) menemukan bahwa bahwa ASN cenderung tidak melaporkan kecurangan apabila mereka menganggap kecurangan tersebut kurang atau tidak serius. Akan tetapi, penelitan tersebut menjelaskan sejauh mana interaksi persepsi keseriusan dan insentif keuangan dapat mempengaruhi keputusan melakukan whistleblowing. Alasan kedua adalah penelitian whistleblowing cenderung berfokus kepada pegawai perusahaan atau kantor audit meskipun frekuensi dan dampak korupsi yang melibatkan sektor publik juga relatif signifikan. Berdasarkan hal tersebut, penelitian ini ditujukan untuk menguji sejauh mana intensi aparatur sipil negara dalam melaporkan kecurangan dipengaruhi oleh persepsi keseriusan dan insentif keuangan. Hal ini diperlukan untuk membantu pembuat kebijakan dalam merumuskan kebijakan yang dapat mendeteksi kecurangan sedini mungkin, seperti whistleblowing. Selain itu, hasil penelitian diharapkan juga dapat berkontribusi kepada literatur tentang pendeteksian fraud khususnya di lingkungan pemerintahan serta memberikan saran kepada pembuat kebijakan untuk mengevalusi signifikansi dampak kebijakan insentif keuangan di kalangan ASN. Pada bagian selanjutnya akan dibahas metodologi, hasil dan diskusi, serta kesimpulan.

\section{METODE}

Penelitian ini menggunakan metode between-subject experimental design, dimana peserta diharapkan tidak dapat menjadi bagian dari control group dan experiment-group secara bersamaan sehingga dapat menghindari efek carryover yang membuat hasil penelitian tidak dapat diandalkan (Charness, Gneezy, \& Kuhn, 2012). Dengan menggunakan between subject-subject experimental design, responden dibagi menjadi kedua kelompok dimana masing-masing kelompok tersebut menghadapi skenario yang berbeda tentang insentif keuangan. Penelitian ini memiliki dua variabel independen (insentif keuangan dan persepsi keseriusan) dan satu variabel dependen (intensi melakukan whistleblowing kepada pihak eksternal). Variabel intensi melakukan whistleblowing dan persepsi keseriusan diukur dengan menggunakan Likert skala 5. Variabel insentif keuangan merupakan variabel manipulatif dimana insentif keuangan dimanipulasi ke dalam dua tingkatan, yaitu keberadaan dan ketiadaan insentif keuangan. Variabel insentif keuangan diukur dengan menggunakan variabel dummy, yaitu 1 untuk ketiadaan insentif keuangan dan 2 untuk keberadaan insentif keuangan.

Sebanyak 160 kuesioner dikirim kepada ASN di tiga institusi publik. Akan tetapi, ketiadaan data mengenai daftar pegawai negeri di Indonesia, mengakibatkan pemilihan sampel dilakukan dengan metode sampling kemudahan (convenience sampling). Pengiriman kuesioner ke intitusi pemerintah pusat dilakukan melalui bagian humas institusi terkait di bulan Maret sampai dengan Mei 2019. Kuesioner yang kembali berjumlah 134 buah dan hanya 107 kuesioner (66,9\%) yang diisi secara lengkap dan dapat digunakan untuk dianalisis.

Dalam kuesioner, responden ditanya mengenai umur, jenis kelamin, golongan jabatan, dan lama bekerja. Responden juga menerima sebuah skenario dimana responden dihadapkan pada situasi untuk memeriksa realisasi anggaran kegiatan operasional seperti pembelian, biaya transportasi (bensin, parkir, tol), alat tulis, materai, dan lainnya di tempat dia bekerja. Kasus korupsi dengan skenario pemalsuan dokumen dan pembayaran kepada vendor dipilih karena jumlah kasus tersebut 
tergolong signfikan pada sektor publik. Data KPK pada tahun 2017 dan 2018 menunjukkan bahwa 310 kasus atau 68,9\% dari keseluruhan kasus korupsi yang ditangani KPK dari tahun 2014-2018 terjadi pada sektor publik. Delapan puluh dua kasus di antaranya (18,2\%) melibatkan eselon I sampai IV.

Dalam skenario yang diberikan, responden menemukan adanya dokumen-dokumen yang mengindikasikan telah terjadi penyalahgunaan anggaran sebesar 5 milyar rupiah untuk kepentingan pribadi salah seorang kepala bagian di tempat responden bekerja. Selain itu, terdapat banyak bukti transaksi yang tidak resmi dari vendor terkait seperti faktur/tagihan yang tidak memiliki informasi mengenai tanggal pembelian, serta tidak adanya cap resmi vendor. Hal tersebut membuat responden melakukan pengecekan apakah vendor tersebut vendor fiktif atau tidak. Setelah melakukan pengecekan dengan beberapa cara, antara lain mencari informasi di internet mengenai keberadaan vendor, menelpon vendor sesuai infomasi yang tertera di faktur, dan/atau mendatangi vendor secara langsung, responden menemukan bahwa vendor tersebut tidak pernah ada (fiktif). Responden memperkirakan bahwa telah terjadi penyalahgunaan anggaran sebesar 5 milyar rupiah yang telah menyebabkan beberapa program tidak berjalan sebagaimana mestinya, serta berpotensi menurunkan reputasi institusi tempat responden bekerja.

Responden selanjutnya dihadapkan dengan variabel manipulatif, yaitu insentif keuangan. Kelompok responden yang pertama mendapat informasi bahwa responden tidak akan diberikan insentif keuangan apabila responden melaporkan pelanggaran di atas, meskipun si pelaku pelanggaran dinyatakan terbukti bersalah. Kelompok responden yang kedua menerima informasi tambahan bahwa menurut PP No 43 Tahun 2018, pemerintah akan memberikan imbalan moneter kepada individu yang secara sukarela memberikan informasi mengenai kesalahan/kecurangan dalam suatu organisasi kepada otoritas terkait. Jumlah insentif keuangan yang diberikan adalah $2 \%$ (2 per-mii) dari total kerugian yang dikembalikan ke negara dan jumlah maksimum dari insentif yang diberikan adalah 200 juta rupiah. Dengan kata lain, jika responden melaporkan kasus di atas, maka responden akan mendapatkan insentif maksimal sebesar 10 juta rupiah (5 Milyar x $2 \% 0$ ). Pemberian insentif diberikan paling lama setelah tiga bulan dari tanggal pelaporan dan pelaku pelanggaran dinyatakan bersalah.

Setelah responden membaca skenario pelanggaran di atas, setiap responden diminta menjawab dua pertanyaan. Pada pertanyaan pertama, responden diminta menjawab seberapa serius pelanggaran di dalam skenario tersebut. Selanjutnya, responden diperhadapkan dengan pertanyaan seberapa besar kemungkinan mereka melaporkan pelanggaran yang mereka temukan kepada pihak eksternal seperti kepolisian dan KPK. Pertanyaan kedua dimaksudkan untuk mengukur variabel dependen. Studi ini memilih pelaporan secara eksternal sebagai variabel dependen karena PP No 43 Tahun 2018 pasal 7 dan 8 menyatakan bahwa pemberi informasi (whistleblower) menyampaikan informasi kepada penegak hukum dengan membuat laporan tertulis yang berisi antara lain identitas pelapor dan uraian fakta dugaan terjadinya tindak pidana korupsi (Republik Indonesia, 2018). Studi sebelumnya menujukkan bahwa intensi pelapor untuk melaporkan pelanggaran cenderung menurun saat mereka mereka harus mengungkapkan identitas pribadi atau pada saat mereka meyakini bahwa risiko identitas mereka terungkap ke pihak lain semakin besar (Curtis \& Taylor, 2009).

\section{HASIL DAN PEMBAHASAN}

Tabel 3 memberikan gambaran mengenai responden penelitian dimana sebagian besar responden merupakan golongan tiga (84,1\%). Responden juga terdiri $58,9 \%$ pria dan sekitar setengah jumlah responden $(59,8 \%)$ berusia kurang dari 30 tahun.

Tabel 3. Informasi Demografi

\begin{tabular}{ccc}
\hline & $\mathbf{N}$ & Percentase \\
\hline Total Partisipan & 107 & $100 \%$ \\
Pria & Jenis Kelamin & \\
Wanita & 63 & $58,9 \%$ \\
IV & 44 & $41,1 \%$ \\
III & Golongan & $0.0 \%$ \\
II & 0 & $84,1 \%$ \\
I & 90 & $15,9 \%$ \\
Usia & 17 & $0,0 \%$ \\
\hline Dibawah 30 tahun & 0 & $59,8 \%$ \\
$\mathbf{3 0}-\mathbf{3 9}$ tahun & & $34,6 \%$ \\
$\mathbf{4 0}$ - $\mathbf{9}$ tahun & 64 & $2,8 \%$ \\
$\mathbf{5 0}$ tahun ke atas & 37 & $2,8 \%$ \\
\hline
\end{tabular}


Pulungan, Afriani, Hasudungan - Apakah insentif keuangan... $\mid 5$

Tabel 4. Statistik Deskriptif

\begin{tabular}{llll}
\hline Panel A & & \\
Frekuensi Persepsi & Level Keseriusan & Jumlah Responden & Persentase \\
Keseriusan & 1 - Sangat Tidak Serius & 2 & $1,9 \%$ \\
& 2 & 2 & $1,9 \%$ \\
& 3 & 12 & $11,2 \%$ \\
& 4 & 31 & $29,0 \%$ \\
& 5 - Sangat Serius & 60 & $56,1 \%$ \\
\cline { 2 - 3 } & Total & 115 & $100,0 \%$ \\
\hline Panel B & & & \\
Frekuensi Insentif & Insentif Keuangan & Jumlah Responden & Persentase \\
Keuangan & $1-$ Tidak Ada & 58 & $54,2 \%$ \\
& $2-$ Ada & 49 & $45,8 \%$ \\
\hline
\end{tabular}

Tabel 5. Intensi Melaporkan Pelanggaran kepada Pihak Eksternal

\begin{tabular}{|c|c|c|c|c|}
\hline Panel A: Rata-Rata & & & & \\
\hline Insentif Keuangan & Rata-Rata & Std. Deviasi & & \\
\hline Tidak Ada & 3,59 & 1,109 & & \\
\hline Ada & 3,63 & ,994 & & \\
\hline Panel B: Analisis Korelasi & & & & \\
\hline & $\begin{array}{c}\text { Intensi Mela } \\
\text { Kepada }\end{array}$ & $\begin{array}{l}\text { n Pelanggaran } \\
\text { Eksternal }\end{array}$ & & \\
\hline Persepsi Keseriusan & & & & \\
\hline Sig (two-tailed) & & & & \\
\hline $\mathrm{N}$ & & & & \\
\hline Insentif Keuangan & & & & \\
\hline Sig (two-tailed) & & & & \\
\hline $\mathrm{N}$ & & & & \\
\hline Panel C: Hasil Uji Ancova & & & & \\
\hline Sumber & B & Std. Error & $\mathrm{F}$ & Sig \\
\hline Efek Utama (Full factorial Model) & & & & \\
\hline Keseriusan & 0,591 & 0,100 & 34,895 & 0,000 \\
\hline Insentif Keuangan & $-0,055$ & 0,178 & 0,096 & 0,757 \\
\hline Interaksi (Interaction Model) & & & & \\
\hline Insentif Keuangan x Keseriusan & 0,612 & 0,182 & 10,131 & 0,002 \\
\hline
\end{tabular}

Studi ini bertujuan menguji pengaruh persepsi keseriusan dan insentif keuangan, dan interaksi kedua variabel tersebut terhadap intensi aparatur sipil negara melaporkan pelanggaran kepada pihak eksternal. Tabel 4 memperlihatkan bahwa sebanyak 91 responden $(85,1 \%)$ menganggap bahwa korupsi yang dipaparkan di dalam skenario adalah serius (29\%) dan sangat serius (56,1\%). Jumlah responden yang menerima kuesioner berisi skenario ketiadaan insentif keuangan kepada whistleblower (54,2\%) lebih banyak dibandingkan dengan jumlah responden yang menjawab kuesioner dengan skenario bahwa mereka akan menerima insentif keuangan jika responden melaporkan pelanggaran (45,8\%).

Studi ini bertujuan menguji pengaruh persepsi keseriusan dan insentif keuangan, dan interaksi kedua variabel tersebut terhadap intensi aparatur sipil negara melaporkan pelanggaran kepada pihak eksternal. Tabel 4 memperlihatkan bahwa sebanyak 91 responden $(85,1 \%)$ menganggap bahwa korupsi yang dipaparkan di dalam skenario adalah serius (29\%) dan sangat serius $(56,1 \%)$. Jumlah responden yang menerima kuesioner berisi skenario ketiadaan insentif keuangan kepada whistleblower (54,2\%) lebih banyak dibandingkan dengan jumlah responden yang menjawab kuesioner dengan skenario bahwa mereka akan menerima insentif keuangan jika responden melaporkan pelanggaran (45,8\%).

Studi ini bertujuan menguji pengaruh persepsi keseriusan dan insentif keuangan, dan interaksi kedua variabel tersebut terhadap intensi aparatur sipil negara melaporkan pelanggaran kepada pihak eksternal. Tabel 4 memperlihatkan bahwa sebanyak 91 responden $(85,1 \%)$ menganggap bahwa korupsi yang dipaparkan di dalam skenario adalah serius (29\%) dan sangat serius (56,1\%). Jumlah responden yang menerima kuesioner berisi skenario ketiadaan insentif keuangan kepada whistleblower (54,2\%) lebih banyak dibandingkan dengan jumlah responden yang menjawab kuesioner dengan skenario bahwa mereka akan menerima insentif keuangan jika responden melaporkan pelanggaran (45,8\%). 


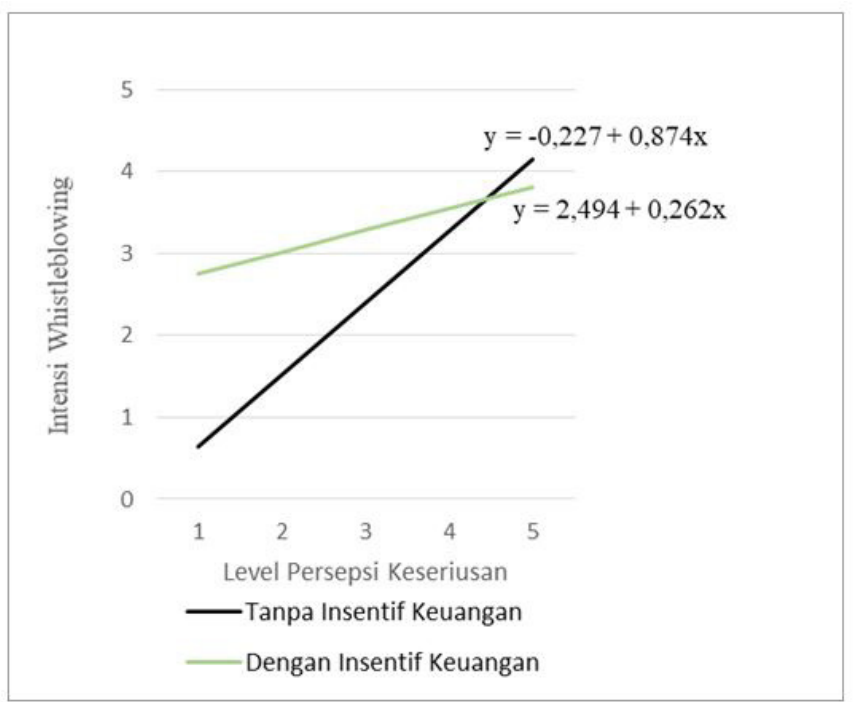

Gambar 2. Interaksi antara Persepsi Keseriusan dan Insentif Keuangan

Tabel 6. Intensi Whistleblowing Kepada Pihak Eksternal Berdasarkan Jenis Kelamin, Usia, dan Golongan

\begin{tabular}{|c|c|c|c|c|}
\hline \multicolumn{5}{|c|}{ Panel A Hasil Uji Ancova Berdasarkan Jenis Kelamin } \\
\hline \multirow{4}{*}{$\begin{array}{l}\text { Beta } \\
\text { Sig. }\end{array}$} & \multicolumn{2}{|c|}{ Pria } & \multicolumn{2}{|c|}{ Wanita } \\
\hline & Keseriusan & Insentif Keuangan & Keseriusan & Insentif Keuangan \\
\hline & ,765 &, 170 & ,398 &,- 421 \\
\hline & 0,000 & 0,446 & 0,009 & 0,132 \\
\hline \multicolumn{5}{|c|}{ Panel B Hasil Uji Ancova Berdasarkan Golongan } \\
\hline & \multicolumn{2}{|c|}{ Golongan II } & \multicolumn{2}{|c|}{ Golongan III } \\
\hline & Keseriusan & Insentif Keuangan & Keseriusan & Insentif Keuangan \\
\hline Beta & ,667 &, 167 &, 564 &,- 063 \\
\hline Sig. & 0,003 & 0,742 & 0,000 & 0,754 \\
\hline \multicolumn{5}{|c|}{ Panel C Hasil Uji Ancova Bedasarkan Usia } \\
\hline & \multicolumn{2}{|c|}{ Di bawah 30 tahun } & \multicolumn{2}{|c|}{$30-39$ tahun } \\
\hline & Keseriusan & Insentif Keuangan & Keseriusan & Insentif Keuangan \\
\hline Beta & ,628 &,- 155 & ,488 & ,291 \\
\hline Sig. & 0,000 & 0,474 & 0,012 & 0,386 \\
\hline
\end{tabular}

Tabel 5 Panel B menunjukkan bahwa persepsi keseriusan berkorelasi positif signifikan (p-value $<0,001)$ terhadap intensi melakukan whistleblowing kepada pihak eksternal. Setelah dilakukan uji ancova (Analysis of Covariate di Panel C Tabel 5), terlihat bahwa persepsi keseriusan secara signifikan mempengaruhi keputusan ASN melaporkan pelanggaran. Apabila seorang ASN menilai suatu pelanggaran atau kecurangan semakin serius, semakin besar intensi ASN untuk melaporkan pelanggaran tersebut $(F=34,895, \beta=0,591$, $p$-value $<0,001)$. Hasil yang berbeda ditunjukkan oleh pengaruh insentif keuangan terhadap intensi whistleblowing. Insentif keuangan tidak berkorelasi dengan terhadap intensi whistleblowing $(\mathrm{p}$-value $=0,821)$ sebagaimana terlihat pada Tabel 5 Panel B. Hasil uji Ancova mengindikasikan bahwa insentif keuangan tidak berpengaruh signifikan terhadap keputusan aparatur sipil negara melakukan whistleblowing kepada pihak eksternal $(\beta=-0,055, \mathrm{~F}=$ 0,096. p-value $=0,757)$.

Tabel 5 Panel C memperlihatkan dampak bersama insentif keuangan dan persepsi keseriusan (insentif keuangan $\mathrm{x}$ keseriusan) yang signifikan terhadap terhadap intensi aparatur sipil negara melakukan whistleblowing $(\beta=0,612, \mathrm{~F}=10,131$, $\mathrm{p}$-value $=0,002)$. Intensi aparatur sipil negara untuk melaporkan korupsi meningkat secara signifikan saat persepsi keseriusan meningkat, terlepas dari ada atau tidaknya insentif keuangan (Gambar 2). Dengan kata lain, pengaruh imbalan moneter akan menjadi kurang penting saat seorang whistleblower memandang dampak suatu kecurangan serius secara signifikan, maka motivasi intrinsik akan menjadi lebih dominan saat memutuskan melaporkan pelanggaran tersebut. Sebaliknya, saat tingkat persepsi keseriusan rendah, keberadaan insentif keuangan dapat meningkatkan intensi aparatur sipil negara melaporkan pelanggaran kepada pihak eksternal.

Dengan membagi sampel berdasarkan jenis kelamin, golongan, dan usia, penelitian ini menganalisa lebih jauh apakah insentif keuangan dan persepsi keseriusan memiliki pengaruh yang berbeda terhadap intensi keputusan whistleblowing ASN pada setiap kriteria sampel. Tabel 6 
memperlihatkan bahwa pengaruh persepsi keseriusan (motivasi intrinsik) tetap merupakan faktor yang menentukan keputusan ASN di setiap kelompok sampel. Misalnya, pengaruh persepsi keseriusan pada ASN pria $(p<0,001)$ dan wanita $(p=0,009)$ sama-sama signifikan. Sebaliknya insentif keuangan tidak berpengaruh signifikan pada keputusan whistleblowing ASN wanita $(p=0,132)$ maupun pria (sig. $=0,446)$. Persepsi keseriusan juga menjadi faktor signifikan bagi golongan II $(\mathrm{p}=0,03)$ maupun golongan III ( $p<0,001$ ) dalam menentukan apakah akan melaporan suatu kecurangan atau tidak. Oleh karena sampel yang tidak memadai untuk usia 40-49 tahun dan di atas 50 tahun, analisis Ancova berdasarkan usia hanya dapat dibagi ke dalam kriteria, yaitu di bawah 30 tahun dan 30-39 tahun. Hasil uji Ancova menunjukkan hanya persepsi keseriusan yang berdampak positif signifikan di kedua kelompok usia tersebut ( $\mathrm{p}$-value $<0,001$ dan p-value $=0,012$ ).

\section{Pembahasan}

Whistleblowing merupakan salah satu metode untuk mendeteksi kecurangan sedini mungkin. Akan tetapi, agar sistem whistleblowing dapat diterapkan secara efektif, organisasi perlu memahami berbagai faktor yang memengaruhi keputusan seseorang melakukan whistleblowing. Near \& Miceli (1995, dikutip oleh Lei \& Brink, 2017) menyebutkan bahwa ada berbagai faktor yang dapat mempengaruhi keputusan seseorang dalam memutuskan apakah akan melaporkan suatu pelanggaran, antara lain karakteristik personal pelapor, serta dampak yang ditimbulkan oleh pelanggaran. Penelitian ini, secara khusus, membagi faktor yang mempengaruhi keputusan seseorang melakukan whistleblowing menjadi faktor intrinsik dan ekstrinsik.

Teori motivasi ekstrinsik-intrinsik mengemukakan bahwa keputusan seseorang dapat dimotivasi dari dalam (intrinsik) maupun dari luar (ekstriksik) diri seseorang (Ryan \& Deci, 2000). Hasil penelitian ini memperlihatkan keputusan ASN untuk melakukan whistleblowing lebih dipengaruhi oleh persepsi mereka mengenai seberapa serius dampak yang ditimbulkan oleh suatu pelanggaran. Hal tersebut konsisten dengan penelitian sebelumnya di sektor pemerintahan (Winardi, 2013) dan sektor swasta (Andon, Free, Jidin, Monroe, \& Turner, 2018; Taylor \& Curtis, 2013). Winardi (2013) meneliti pengaruh persepsi keseriusan pada ASN bergolongan rendah. Hasilnya ASN lebih cenderung melaporkan pelanggaran saat mereka menilai pelanggaran tersebut lebih serius. Dengan menggunakan partisipan yang lebih besar (2.081 partisipan) dan dari berbagai kalangan, Feldman \& Lobel (2010) juga menemukan bahwa intensi partisipan untuk melaporkan suatu pelanggaran akan meningkat seiring dengan persepsi mereka akan berbahayanya (severity) suatu pelanggaran.

Ada beberapa alasan yang menyebabkan mengapa faktor intrinsik (persepsi keseriusan) lebih dominan dalam mempengaruhi keputusan ASN untuk melakukan whistleblowing. Alasan pertama adalah adanya pemikiran bahwa institusi akan lebih cenderung mengambil tindakan korektif atas pelanggaran yang serius dibandingkan pelanggaran yang dianggap kurang serius (Near \& Miceli, 1985). Tingkat keseriusan suatu pelanggaran tidak hanya diukur oleh kerugian finansial (materialitas), tetapi juga dari seberapa besar probabilitas kerugian tersebut terjadi (Curtis, 2006). Semakin besar probabilitas terjadinya dampak suatu pelanggaran yang membahayakan orang lain, maka semakin tinggi tingkat keseriusan pelanggaran tersebut. Dengan kata lain, persepsi keseriusan merupakaan kombinasi dari seberapa material dampak yang ditimbulkan suatu pelanggaran dan probabilitas terjadinya dampak atau kerugian.

Semakin tinggi tingkat keseriusan suatu pelanggaran, maka semakin besar pula perlunya tindakan korektif. Tindakan korektif dilakukan untuk melindungi institusi dari kerugian yang lebih besar yang disebakan oleh pelanggaran yang lebih serius. Institusi memiliki peran untuk mengedukasi pegawai dalam membedakan antara pelanggaran yang material dengan yang tidak material sebab materialitas merupakan elemen utama yang mempengaruhi persepsi pegawai akan tingkat keseriusan suatu pelanggaran (Ayers \& Kaplan, 2005; Finn, 1995 dikutip dari Taylor \& Curtis, 2010).

Kedua, lebih dominannya faktor intrinsik dalam mempengaruhi keputusan whistleblowing ASN dapat disebabkan oleh motivasi seseorang bekerja di sektor pemerintahan yang lebih didorong oleh keinginan untuk berkontribusi kepada kepentingan publik daripada kepentingan diri sendiri (Vandenabeele 2007, dikutip dari Anderfuhren-Biget, Varone, Giaque, Ritz, 2015). Akibatnya, faktor ekstrinsik, khususnya imbalan moneter tidak memiliki pengaruh yang kuat untuk memotivasi ASN dalam bekerja. Sebagai contoh, sebuah penelitian di Swiss memperlihatkan bahwa pengaruh penghargaan moneter memiliki pengaruh yang lemah terhadap motivasi ASN (Anderfuhren-Biget, Varone, Giauque, \& Ritz, 2010). Insentif keuangan akan mempengaruhi ASN hanya dalam situasi tertentu, misalnya saat mereka menilai pekerjaan mereka kurang menarik (Buelens \& Van Den Broeck, 2007). Alasan ketiga adalah insentif keuangan yang ditawarkan oleh regulasi hanya akan mempengaruhi intensi pelaporan kecurangan hanya jika kecurangan tersebut dianggap tidak morally offensive atau tidak mencederai nilai-nilai moralitas (Feldman \& Lobel, 2010). Pelaporan kecurangan yang lebih dimotivasi oleh faktor imbalan moneter (faktor ekstrinsik) tanpa memperhatikan keseriusan 
pelanggaran tersebut dapat mengakibatkan lebih banyak tuntutan hukum kepada pelapor, khususnya untuk kasus-kasus yang tidak serius (Andon, Free, Jidin, Monroe, \& Turner, 2018). Tuntutan hukum juga akan mengakibatkan lebih banyak pekerjaan administrasi yang mungkin tidak sebanding dengan dampak yang ditimbulkan oleh korupsi tersebut. Oleh sebab itu, ASN akan lebih berhati-hati dalam melaporkan suatu kasus pelanggaran. Mereka akan lebih cenderung memperhatikan besarnya dampak suatu pelanggaran daripada imbalan insentif yang akan mereka terima.

\section{SIMPULAN}

Studi ini menguji sejauh mana imbalan moneter (motivasi ekstrinsik) dan persepsi keseriusan (motivasi intrinsik) mempengaruhi keputusan whistleblowing ASN. Dengan menggunakan metode between-subject experimental, penelitian ini menemukan bahwa keputusan ASN melaporkan pelanggaran kepada pihak eksernal tidak dipengaruhi oleh motivasi eksternal, khususnya insentif keuangan. Keputusan ASN melakukan whistleblowing lebih dipengaruhi oleh motivasi intrinsik yaitu pandangan mereka mengenai seberapa serius pelanggaran tersebut. Semakin serius sebuah pelanggaran, semakin besar kecenderungan ASN melaporkan kecurangan tersebut kepada pihak eksternal seperti KPK maupun kepolisian. Hasil pengujian interaksi antara persepsi keseriusan dan insentif keuangan mengindikasikan bahwa pengaruh persepsi keseriusan memoderasi pengaruh insentif keuangan, yaitu intensi ASN melaporkan kecurangan semakin tinggi saat keseriusan kecurangan semakin tinggi meskipun tanpa ada insentif keuangan.

Sekalipun hasil penelitian memberikan bukti bahwa faktor ekstrinsik tidak memiliki pengaruh yang signifikan terhadap keputusan ASN dalam melakukan whistleblowing, bukan berarti PP No 43 Tahun 2018 tidak efektif. Hal ini justru membuka ruang bagi penelitian di masa yang akan datang untuk menguji kapan atau pada kondisi bagaimana imbalan moneter yang ditawarkan pemerintah dapat mempengaruhi secara signifikan keputusan whistleblowing. Penelitian ini juga membuka kesempatan bagi penelitian selanjutnya untuk mengatasi beberapa keterbatasan pada metode penelitian ini, terutama pengambilan sampel yang hanya dari tiga institusi publik dengan metode convenience sampling. Penelitian di masa yang akan datang dapat menguji faktor lainnya yang dapat mempengaruhi keputusan whistleblowing aparatur sipil negara, atau menggunakan sampel yang lebih luas dan lebih reprensentatif. Selain itu, penelitian yang akan datang juga dapat menganalisa apakah terdapat perbedaan antara faktor yang mempengaruhi keputusan whistleblowing di sektor publik dan sektor swasta.

\section{DAFTAR RUJUKAN}

Anderfuhren-Biget, S., Varone, F., Giauque, D., \& Ritz, A. (2010). Motivating Employees of the Public Sector: Does Public Service Motivation Matter? International Public Management Journal, 13(3), 213-246. doi:10.1080/10967494.2010.503783

Andon, P., Free, C., Jidin, R., Monroe, G. S., \& Turner, M. J. (2018). The Impact of Financial Incentives and Perceptions of Seriousness on Whistleblowing Intention. Journal of Business Ethics, 151(1), 165-178. doi:10.1007/s10551-016-3215-6

Andon, P., Free, C., Jidin, R., Monroe, G. S., \& Turner, M. J. (2018). The Impact of Financial Incentives and Perceptions of Seriousness on Whistleblowing Intention. Journal of Business Ethics, 151(1), 165-178.

Ayers, S., \& Kaplan, S. E. (2005). Wrongdoing by Consultants: An Examination of Employees' Reporting Intentions. Journal of Business Ethics, 572), 121-137. doi:10.1007/s10551-004-4600-0

Buelens, M., \& Van Den Broeck, B. (2007). An Analysis of Differences in Work Motivation between Public and Private Sector Organizations. Public Administration Review, 671), 65-74. doi:10.1111/ j.1540-6210.2006.00697.x

Charness, G., Gneezy, U., \& Kuhn, M. A. (2012). Experimental methods: Between-subject and within-subject design. Journal of Economic Behavior \& Organization, 81(1), 1-8. doi:10.1016/j.jebo.2011.08.009

Curtis, M. B. (2006). Are Audit-related Ethical Decisions Dependent Upon Mood?. Journal of Business Ethics, 68(2), 191-209. doi:10.1007/s10551-006-9066-9

Curtis, M. B., \& Taylor, E. Z. (2009). Whistleblowing in Public Accounting: Influence of Identity Disclosure, Situational Context, and Personal Characteristics. Accounting and the Public Interest, 9(1), 191-220. doi:10.2308/api.2009.9.1.191 
Deci, E. L., \& Ryan, R. M. (1985). Intrinsic Motivation and Self-Determination in Human Behavior. New York: Plenum.

Dobbs, I. M., \& Miller, A. D. (2009). Experimental Evidence on Financial Incentives, Information, and Decision Making. The British Accounting Review, 41(2), 71-89. doi:10.1016/j.bar.2008.10.002

Feldman, Y., \& Lobel , O. (2010). The Incentives Matrix: The Comparative Effectiveness of Rewards, Liabilities, Duties and Protections for Reporting Illegality. Texas Law Review, 87. doi:10.2139/ ssrn. 1415663

Komisi Pemberantasan Korupsi. (2017). Laporan Tahunan KPK 2017.Jakarta: Komisi Pemberantasan Korupsi.

Komisi Pemberantasan Korupsi. (2018, Desember 20). Capaian dan Kinerja KPK di Tahun 2018. Retrieved from www.kpk.go.id: https://www.kpk.go.id/id/berita/siaran-pers/717-capaian-dankinerja-kpk-di-tahun-2018

Kruglanski, A. W. (1978). Endogenous Attribution and Intrinsic Motivation. In M. R. Lepper, \& D. Greene, The Hidden Cost of Reward: New Perspectives on the Psychology of Human Motivation (pp. 85-107). New Jersey: Lawrence Eribaum Associates, Inc.

Lei, G., \& Brink, A. G. (2017). Whistleblowing studies in accounting research: A review of experimental studies on the determinants of whistleblowing. Journal of Accounting Literature, 38, 1-13.

Near, J. P., \& Miceli, M. P. (1985). Organizational Dissidence: The Case of Whistle-Blowing. Journal of Business Ethics, 4(1), 1-16.

Near, J. P., \& Miceli, M. P. (1995). Effective Whistle-Blowing. The Academy of Management Review, 20(3), 679-708.

Pope, K. R., \& Lee, C.-C. (2012). Could the Dodd-Frank Wall Street Reform and Consumer Protection Act of 2010 be Helpful in Reforming Corporate America? An Investigation on Financial Bounties and Whistle-Blowing Behaviors in the Private Sector. Journal of Business Ethics, 112(4), 597-607. doi:10.1007/s10551-012-1560-7

Republik Indonesia. (2018). Peraturan Pemerintah No 43 Tahun Tata Cara Pelaksanaan Peran Serta Masyarakat dan Pemberian Penghargaan Dalam Pencegahan dan Pemberantasan Tindak Pidana Korupsi.

Ryan, R. M., \& Deci, E. L. (2000). Intrinsic and Extrinsic Motivations: Classic Definitions and New Directions. Contemporary Educational Psychology, 25(1), 54-67. doi:10.1006/ceps.1999.1020

Stikeleather, B. R. (2016). When do Employers Benefit from Offering Workers a Financial Reward for Reporting Internal Misconduct? Accounting, Organizations and Society, 52, 1-14.

Taylor, E. Z., \& Curtis, M. B. (2010). An Examination of the Layers of Workplace Influences in Ethical Judgments: Whistleblowing Likelihood and Perseverance in Public Accounting. Journal of Business Ethics, 93(1), 21-37. doi: 10.1007/s10551-009-0179-9

Taylor, E. Z., \& Curtis, M. B. (2013). Whistleblowing in Audit Firms: Organizational Response and Power Distance. Behavioral Research in Accounting, 25(2), 21-43. doi: 10.2308/bria-50415

Weibel, A., Rost, K., \& Osterloh, M. (2010). Pay for Performance in the Public Sector - Benefits and (Hidden) Costs. Journal of Public Administration Research and Theory: J-PART, 20(2), 387412. Retrieved from http://www.jstor.org/stable/40732516

Winardi, R. D. (2013). The Influence of Individual and Situational Factors on Lower-Level Civil Servants' Whistleblowing Intention in Indonesia. Journal of Indonesian Economy and Business, 28(3), 361-376. Retrieved from https://search.proquest.com/docview/1548716199?account $\mathrm{id}=108784$ 
Halaman ini sengaja dibiarkan kosong. 